\title{
EKSTRAKSI DAUN SIRIH, BATANG SEREH DAN BAWANG MERAH UNTUK PRODUKSI PESTISIDA ORGANIK
}

\author{
Catur Nilan H. ${ }^{*}$, Lianta Monalisa S., Afiyatun Inayah dan Dwi Handayani \\ Teknik Kimia Sekolah Vokasi, Universitas Diponegoro \\ Jl. Prof. Sudarto SH, Tembalang, Semarang, Jawa Tengah Indonesia \\ "Email : nilancatur@gmail.com
}

\begin{abstract}
Abstrak
Daun sirih dengan kandungan alkaloid, steroid, tanin, fenol, saponin, flavonoid, asam amino, bawang merah dengan kandungan allisin dan alliin, flavonoid, alilpropil disulfide, fitosterol, flavonol, pektin, saponin, tripropanal sulfoksida, dan senyawa acetogenin, dan sereh dengan kandungan zat aktif sitronellal, geraniol, dan sitronellol, bahan - bahan tersebut dapat dijadikan sebagai bahan dasar pembuatan pestisida organik karena kandungan zat aktif yang dimilikinya tidak disukai hama perusak tanaman. Kandungan flavonoid yang dimiliki oleh daun sirih dapat mengganggu metabolisme energi didalam mitikondria serangga dengan menghambat system pengangkutan electron, sehingga tidak disukai serangga. Tujuan penelitian ini adalah mengidentifikasi dan menguji kuantitatif senyawa flavonoid dari ekstrak daun sirih (piper batle L.), batang sereh dan bawang merah. Implementasi dalam bentuk kerja laboratorium yaitu menggunakan ekstraktor kohobasi. Identifikasi senyawa flavonoid ekstrak daun sirih, batang sereh dan bawang merah menunjukkan hasil positif jika sampel berubah warna dari coklat dan kuning tua menjadi kuning atau jingga dan bening. Pada uji kuantitatif kadar flavonoid dengan menggunakan spektrofotomoter type UV - Vis didapat hasil pengujian ekstrak variabel 1 yaitu : $0.5724 \%, 0.504 \%, 0.5364 \%, 0.5424 \%, 0.4425$ dan variabel 2 yaitu: 0.201\%, 0.291\%, 0.327\%, 0.273\%, 0.246\%. Jadi pada pengujian kadar flavonoid yang diperoleh menunujukkan bahwa banyaknya variabel pelarut berpengaruh terhadap kadar flavonoid karena hasil yang diperoleh menghasilkan perbedaan kadar flavonoid yang signifikan.
\end{abstract}

Kata kunci: ekstrak, flavonoid, daun sirih

\section{PENDAHULUAN}

Pestisida organik adalah salah satu upaya para petani untuk menekan dampak negatif yang ditimbulkan dari pestisida non hayati yang dapat merusak lingkungan, dalam rangka untuk memepertahankan produksi pertanian dan perkebunan (Fenty,2015).

Sirih merupakan tanaman yang merambat pada batang pohon lain. Kandungan daun sirih terdiri dari alkaloid, steroid, tanin, fenol, saponin, flavonoid, dan asam amino (Shetty, 2012). Kandungan flavonoid yang dimiliki oleh daun sirih dapat mengganggu metabolism energi didalam mitikondria serangga dengan menghambat system pengangkutan electron (Ifni, 2017).

Bawang merah merupakan tanaman yang memiliki umbi, pada kulit dan dagingnya berwarna ungu kemerahan. Bawang merah dapat hidup di dataran tinggi. Senyawa aktif yang dimiliki bawang merah yaitu Allisin dan Alliin, Flavonoid, Alilpropil disulfide,
Fitosterol, Flavonol, Pektin, Saponin, Tripropanal sulfoksida, dan senyawa acetogenin (Prabowo, 2007). Kandungan yang dimiliki bawang merah yaitu senyawa actogenin dan Flavonol inilah yang mampu untuk membasmi hama tanaman pengganggu, yang berfungsi sebagai anti-feeden dan bersifat racun pada serangga dan hama (Plantus, 2008).

Sereh merupakan anggota dari suku rumput - rumputan yang memiliki batang tanaman sereh bergerombol dan berumbi, serta lunak dan berongga yang memiliki warna putih. Secara umum, sereh dibagi menjadi 2 jenis, yaitu sereh dapur (lemongrass) dan sereh wangi (sitronella). Minyak sereh di Indonesia yang sering digunakan yaitu minyak sereh wangi (citronella oil) yang biasanya terdapat dalam komposisi minyak tawon dan minyak gandapura (Ridwan, 2013). Kandungan zat aktif yang dimiliki sereh yaitu sitronellal, geraniol, dan sitronellol (Burdock, 2002). Sitronelol dari minyak atsiri terdiri dari sepasang enansiomer 
(R)-sitronelal dan (S)-sitronelal (Syamsuhidayat, 1991).

Ekstraksi merupakan suatu proses pemisahan dapat berupa zat padat maupun cair, yang mana menggunakan pelarut sebagai media pembantunya. Pada prosesnya, pelarut tersebut mengekstrak substansi yang diinginkan sedang material yang tidak diinginkan tidak ikut larut. Ekstraksi yang menggunakan pelarut didasarkan pada sifat kelarutan komponen terhadap komponen lain dalam suatu campuran (Suyitno, 1989).

Pada penelitian ini diharapkan dapat mengetahui kadar flavonoid dari variasi variabel bahan dan variabel waktu pada ekstrak daun sirih, bawang merah, dan batang sereh, serta dapat mengidentifikasi untuk mengetahui adanya flavonoid pada pestisida organic yang dihasilkan. hama penghisap oleh pestisida organik berbahan dasar daun sirih, bawang merah, dan batang sereh.

\section{METODOLOGI}

\subsection{Bahan}

Daun sirih, batang sereh, bawang merah, air, serbuk $\mathrm{Mg}$, larutan $\mathrm{HCl}$.

Variabel Penelitian:

1. Variabel Kendali :

Suhu ekstraksi $=100^{\circ} \mathrm{C}$

2. Variabel Bebas

Komposisi bahan 1 dan bahan $2=2000$ gr daun sirih, batang sereh 126 gram, dan bawang merah 32 gram.

Variabel pelarut $1=12$ liter

Variabel pelarut $2=20$ liter

Waktu pengambilan sampel yaitu diambil setiap 30 menit selama 150 menit

\subsection{Alat}

Ekstraktor kohobasi, baskom, botol sampel, erlemeyer, gelas ukur, tabung reaksi, labu takar, pipet tetes, pengaduk kaca, sendok, neraca digital, kaca arloji, penjepit, spirtus, pemantik, buret, klem statif, corong kaca, stopwatch, spektrofotometer.

Berikut ini merupakan ekstraktor kohobasi beserta keterangan pada Gambar 1.

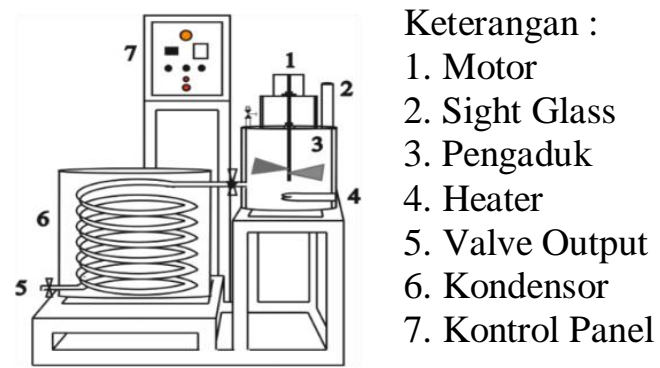

Gambar 1. Ekstraktor Kohobasi

\subsection{Prosedur}

\subsubsection{Pembuatan Pestisida Organik}

Penimbangan variabel 1 pada alat penimbang. Bahan baku berupa daun sirih, batang sereh dan bawang merah di bersihkan terlebih dahulu dan dicuci menggunakan air mengalir. Selanjutnya di potong menjadi bagian yang lebih kecil.

Perangkaian alat ekstraktor dengan baik dan benar, masukan ketiga bahan ke dalam alat ekstraksi dengan penambahan air sesuai variabel 1 dan perhatikan suhu pada alat ekstraksi. Nyalakan pemanas dan pengaduk pada alat ekstraksi tersebut

Pengambilan sampel setiap 30 menit sampai 150 menit, hingga di dapatkan 5 sampel ekstrak. Hal yang sama dilakukan untuk membuat ekstrak pada variabel 2 .

\subsubsection{Pengujian Kadar Flavonoid}

Ekstrak bahan yang terdiri dari daun sirih, batang sereh dan bawang merah dengan menggunakan pelarut air, diukur sampelnya sebanyak $3 \mathrm{ml}$. Masukkan ekstrak bahan tersebut ke dalam tabung reaksi untuk dilakukan pemanasan. Pemanasan dengan menggunakan spirtus. Mulut tabung reaksi di jepit dengan penjepit, selanjutnya dasar tabung reaksi di atas nyala api spirtus. Pemanasan dilakukan selama 5 menit. Angkat tabung reaksi dan masukkan ke dalam wadah tabung reaksi.

Timbang serbuk magnesium sebanyak 0,3 gram dengan nereaca digital. Masukkan serbuk magnesium ke dalam tabung reaksi yang berisi ekstrak. Lakukan titrasi menggunakan larutan $\mathrm{HCl}$ ke dalam tabung reaksi tersebut. Amati perubahan warna yang terjadi, yaitu dari coklat menjadi jingga hingga kuning. Lakukan pengujian secara kuantitatif menggunakan spektrofotometer type UV - Vis untuk memperoleh nilai absorbansi selanjutnya lakukan perhitungan untuk memperoleh kadar ekstrak flavonoid yang didapatkan. Hal yang 
sama dilakukan untuk melakukan analisa pada variabel 2.

\section{HASIL DAN PEMBAHASAN}

\subsection{Variabel 1}

Pada variabel 1 menggunakan volume sampel $3 \mathrm{ml}$ dan penambahan serbuk 0.3 gram menghasilkan data analisa flavonoid yang dapat dilihat pada Tabel 1.

Tabel 1. Hasil Analisa Flavonoid dalam Ekstrak Variabel 1

\begin{tabular}{cccc}
\hline $\begin{array}{c}\text { Menit } \\
\text { Ke }\end{array}$ & $\begin{array}{c}\text { Perubahan } \\
\text { Warna }\end{array}$ & $\begin{array}{c}\text { Absorbansi } \\
(\mathrm{A})\end{array}$ & $\begin{array}{c}\text { Kadar } \\
\text { Flavonoid } \\
(\%)\end{array}$ \\
\hline 30 & $\begin{array}{c}\text { Coklat- } \\
\text { Kuning } \\
\text { Coklat- }\end{array}$ & 0.954 & 0.5724 \\
60 & 0.834 & 0.504 \\
90 & $\begin{array}{c}\text { Kuning } \\
\text { Coklat- } \\
\text { Jingga } \\
\text { Coklat- } \\
\text { Jingga } \\
\text { Coklat- }\end{array}$ & 0.894 & 0.6364 \\
150 & 0.742 & 0.4452 \\
\hline
\end{tabular}

Pada penelitian variabel 1 menggunakan pelarut 12 liter. Menurut Purnama (2017), apabila semua bahan telah di tambahkan akan menyebabkan warna merah, kuning atau jingga pada larutan yang mana warna tersebut menunjukkan adanya kandungan flavonoid. Perubahan warna yang terjadi pada penelitian variabel 1 yaitu dari coklat menjadi kuning pada menit ke 30 dan 60, dan warna jingga pada menit ke 90, 120 dan 150. Warna jingga hingga kuning membuktikan adanya kandungan flavonoid.

Pada penelitian variabel 1, menghasilkan kadar flavonoid yang berbeda - beda. Kadar flavonoid tergantung pada nilai absorbansi, jumlah pelarut dan jumlah variabel daun sirih. Menurut Neldawati, dkk (2013), semakin tinggi kadar flavonoid maka molekul-molekul yang terdapat pada ekstrak daun sirih semakin banyak sehingga molekul yang akan menyerap cahaya pada panjang gelombang tertentu juga semakin banyak, mengakibatkan nilai absorbansi semakin tinggi.

Nilai absorbansi yang di dapat pada penelitian variabel 1 fluktuatif, sehingga menghasilkan kadar yang fluktuatif pula. Pada spektrofotometri dalam penentuan pengukuran spektrum serapan cahaya, semakin pekat warna pada sampel yang diuji maka semakin besar nilai absorbansinya. Sedangkan untuk pelarut kelima sampel menggunakan pelarut sebanyak 12 liter dan untuk variabel daun sirih sebanyak 2000 gram sehingga menghasilkan kadar flavonoid yang di dapat yaitu menit ke 30 $(0,5724 \%)$; menit ke $60(0.504 \%)$; menit ke 90 (0.5364\%); menit ke 120 (0.5424\%); menit ke $150(0.4452 \%)$. Dengan perolehan $\mathrm{y}=$ $0,0216 \mathrm{x}+0,5849$ dan $\mathrm{R}^{2}=0,4981$ yang dapat dilihat pada Gambar 2.

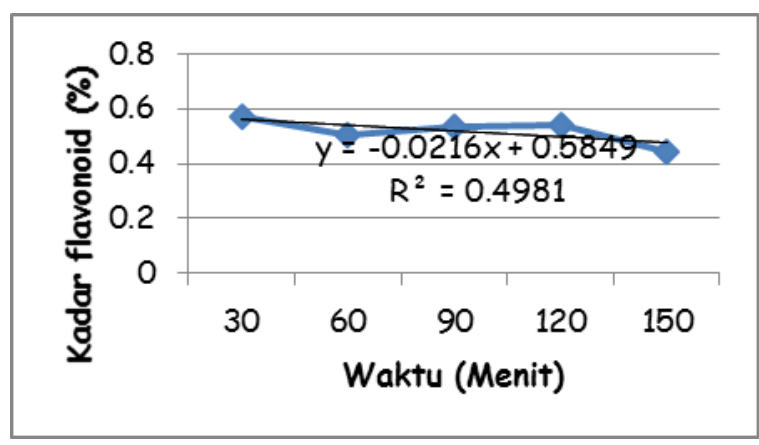

\section{Gambar 2. Grafik Hubungan Waktu dengan Kadar Flavonoid}

Pengaruh waktu dalam perolehan hasil ektraksi disebabkan karena lamanya kontak antara bahan dan pelarut semakin besar sampai batas tidak ada yang terekstraksi (Ningsih, dkk., 2015). Sehingga semakin lama waktu ekstraksi maka semakin banyak ekstrak yang dihasilkan. Ekstrak yang di hasilkan pada variabel 1 mengalami fluktuatif dikarenakan daun sirih yang belum terekstrak ikut keluar sehingga warna sampel menjadi lebih gelap yang menyebabkan nilai absorbansi tinggi sehingga ekstrak yang diperoleh juga tinggi.

\subsection{Variabel 2}

Pada variabel 2 menggunakan volume sampel $3 \mathrm{ml}$ dan penambahan serbuk 0.3 gram menghasilkan data analisa flavonoid yang dapat dilihat pada Tabel 2 . 
Tabel 2. Hasil Analisa Flavonoid dalam Ekstrak Variabel 2

\begin{tabular}{cccc}
\hline $\begin{array}{c}\text { Menit } \\
\text { Ke }-\end{array}$ & $\begin{array}{c}\text { Perubahan } \\
\text { Warna }\end{array}$ & $\begin{array}{c}\text { Absorbansi } \\
(\mathrm{A})\end{array}$ & $\begin{array}{c}\text { Kadar } \\
\text { Flavonoid } \\
(\%)\end{array}$ \\
\hline 30 & $\begin{array}{c}\text { Kuning- } \\
\text { Bening }\end{array}$ & 0.201 & 0.201 \\
60 & $\begin{array}{c}\text { Kuning- } \\
\text { Bening }\end{array}$ & 0.291 & 0.291 \\
90 & $\begin{array}{c}\text { Kuning- } \\
\text { Bening } \\
\text { Kuning- } \\
\text { Bening }\end{array}$ & 0.327 & 0.327 \\
120 & $\begin{array}{c}\text { Kuning- } \\
\text { Bening }\end{array}$ & 0.246 & 0.273 \\
\hline
\end{tabular}

Perubahan warna yang terjadi pada penelitian variabel 2 yaitu dari kuning tua menjadi bening yang menunjukkan adanya kandungan flavonoid. Warna bening dihasilkan dikarenakan $\mathrm{HCl}$ yang digunakan berlebih untuk mentitrasi sampel 1 sampai sampel 5.

Pada penelitian variabel 2, menghasilkan kadar flavonoid yang berbeda - beda. Nilai absorbansi yang di dapat pada penelitian variabel 2 fluktuatif, sehingga menghasilkan kadar yang fluktuatif pula. Sedangkan untuk pelarut kelima sampel menggunakan pelarut sebanyak 20 liter dan untuk variabel daun sirih sebanyak 2000 gram sehingga menghasilkan kadar flavonoid yang di dapat yaitu menit ke $30(0,201 \%)$; menit ke $60(0.291 \%)$; menit ke 90 (0.327\%); menit ke 120 (0.273\%); menit ke $150(0.246 \%)$. Dengan perolehan $\mathrm{y}=0,0072 \mathrm{x}$ $+0,246$ dan $R^{2}=0,0576$ yang dapat dilihat pada Gambar 3.

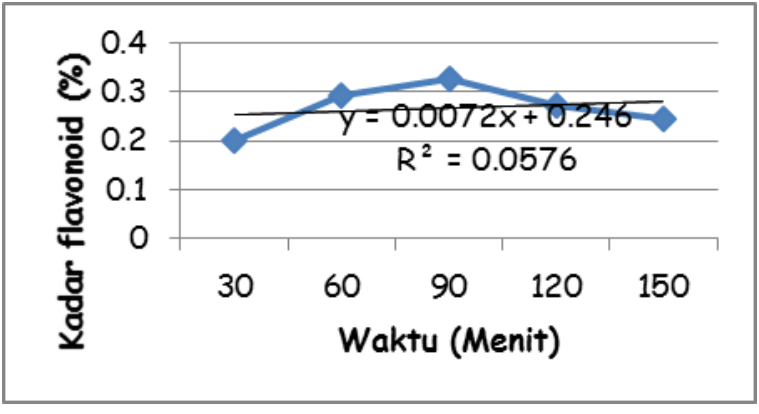

\section{Gambar 3. Grafik Hubungan Waktu dengan Kadar Flavonoid}

Ekstrak yang di hasilkan pada variabel 2 mengalami fluktuatif dikarenakan daun sirih yang belum terekstrak ikut keluar sehingga warna sampel menjadi lebih gelap yang menyebabkan nilai absorbansi tinggi sehingga ekstrak yang diperoleh juga tinggi.

\subsection{Hubungan Waktu dengan Kadar} Flavonoid antara Variabel 1 dan Variabel 2

Pada grafik hubungan waktu dengan kadar flavonoid pada variabel 1 dan variabel 2 menunjukkan bahwa semakin sedikit pelarut yang digunakan yaitu pada variabel 1 maka kadar yang dihasilkan semakin besar, sedangkan semakin banyak pelarut yang digunakan pada variabel 2 maka kadar yang dihasilkan semakin kecil, yang dapat dilihat pada Gambar 4.

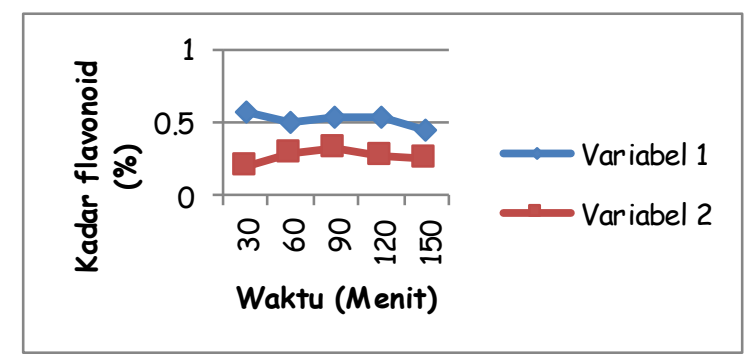
Gambar 4. Grafik Hubungan Waktu dengan
Kadar Flavonoid Variabel 1 dan Variabel 2

Hasil penelitian menunjukkan dengan bertambahnya waktu memberi pengaruh pada kadar flavonoid yang diperoleh dikarenakan jumlah solute sama namun dengan solvent yang berbeda. Terlihat pada grafik pada variabel 1 dan variabel 2 menghasilkan grafik yang tidak berhimpit karena pada kedua variabel menghasilkan kadar yang berbeda.

\section{KESIMPULAN}

Berdasarkan pembuatan pestisida organik berbahan dasar daun sirih, batang sereh dan bawang merah, dilihat dari perubahan warna yang dihasilkan yaitu dari warna coklat dan kuning tua menjadi kuning atau jingga dan bening.

Hasil penelitian menunjukkan dengan bertambahnya waktu yaitu dari menit 30 hingga ke menit 150 memberi pengaruh pada kadar flavonoid yang diperoleh dikarenakan jumlah solute sama namun dengan solvent yang berbeda. Terlihat pada grafik pada variabel 1 dan variabel 2 menghasilkan grafik yang tidak berhimpit karena pada kedua variabel menghasilkan kadar yang berbeda.

\section{SARAN}


Seharusnya dalam melaksanakan praktikum kondisi alat harus diperiksa secara benar benar sebelum menggunakannya, dan dibutuhkan ketelitian untuk mengamati perubahan warna yang terjadi.

\section{DAFTAR PUSTAKA}

Burdock. 2002. Potensi Senyawa Minyak sereh Wangi (Citronella Oil) dari Tumbuhan Cymbopogon nardus L. Sebagai Agen Antibakteri.https://media.neliti.com/ medi a/publications/174438-ID-none.pdf

Fenty. 2015. Tanaman Biopestisida. http://nad. litbang.pertanian.go.id/ind/index .php/info-teknologi/799-tanamanbiopestisida

Ifni. 2017. Pembuatan Pestisida Nabati Menggunakan Metode Ekstraksi Dari Kulit Jengkol Dan Umbi Bawang Putih. https://media.neliti.com/media/publicatio ns/201125-pembuatan-pestisida-nabatimenggunakan-m.pdf

Neldawati, Ratnawulan dan Gusnedi. 2013. Analisis Nilai Absorbansi dalam Penentuan Kadar Flavonoid untuk Berbagai Jenis Daun Tanaman.http://ejournal.unp.ac.id/student s/index.php/fis/article/viewFile/756/513

Ningsih, G., Utami, S. R., dan Nugrahani, R. A., 2015. Pengaruh Lamanya Waktu Ekstraksi Remaserasi Kulit Buah Durian Terhadap Rendemen Saponin Dan Aplikasinya Sebagai Zat Aktif Anti Jamur.https://jurnal.umj.ac.id/index.php/ konversi/article/view/898

Plantus. 2008. Kulit Bawang Merah Sebagai Pestisida Alami Hama Ulat.https:// www. kompasiana.com/baalramadhan/kulitbawang-merah-sebagaipestisida-alamihama-ulat_552fc6436ea834e6368b4592

Prabowo. 2007. Bawang Merah. https://www. kompasiana.com/gubuktani/senyawabioaktif-yang-terdapat-pada-bawang-mer ah-dan-bawangputih54f94802a33311 af068b4a55

Purnama, N. 2017. Identifikasi Senyawa flavonoid pada tumbuhan Daun Sirih (Piper batle L.). conference. unsyiah.ac. id/SN-MIPA/3/ paper/download/997/183

Ridwan. 2013. Klasifikasi dan Morfologi Tanaman sereh (Cymbopogon Cytratus). https://ridwancs97.wordpress.com/2013/ 04/08/klasifikasi-dan-morfologitanaman-sereh-cymbopogon-citratus/
Shetty. 2012. Aktivitas Ekstrak etanol daun Sirih Hijau(Piper betle Linn.) Dalam Proses Persembuhan Luka Infeksi Staphylococcus aureus pada Tikus https://repository.ipb.ac.id/jspui/bitstrea $\mathrm{m} / 123456789 / 61250 / 2 / B 13$ ifa.pdf

Suyitno. 1989. Ekstraksi Kimia. https://anna denina.wordpress.com/2010/08/14/ekstra ksi-kimia/

Syamsuhidayat. 1991. Tanaman Obat Indonesia.lansida.blogspot.com/2011/03/ sereh-cymbopogon-nardus-l-rendle.html? $\mathrm{m}=1$ 